\title{
A qualitative inquiry into customers' perspective on branding and the role of digital technologies in B2B: A case study of Panasonic
}

\author{
Jack Strong $^{1}$ and Elvira Bolat ${ }^{2 *}$ \\ ${ }^{1}$ Department: The Faculty of Management \\ University/Institution: Bournemouth University \\ Email: jack.strongbu@hotmail.co.uk
}

$2 *$ Corresponding Author

Department: Marketing and Strategy, the Faculty of Management University/Institution: Bournemouth University

Work address: C113, Christchurch House, the Business School, Bournemouth University, Poole, United Kingdom, BH12 5BB

Email: ebolat@bournemouth.ac.uk

Tel: (+44) (0)1202968755

\section{Author's Biography}

Jack Strong has recently completed his Business Studies degree in Bournemouth University. He joined the Panasonic Visual System Solutions team in 2013 and is planning to continue his marketing professional career in the $\mathrm{B} 2 \mathrm{~B}$ sector.

Elvira Bolat is a Lecturer in Marketing at Business School, Bournemouth University. Her teaching covers courses on both undergraduate and postgraduate levels. Her research interests cover a digitisation of small and medium sized firms and its effect on service innovations practices. In the last six years she was specifically interested in exploring the value of mobile technology within the service innovations processes. She has an extensive 
interest in the Business to Business (B2B) Marketing research area, hence, Elvira is the acting Deputy Chair for the Academy of Marketing B2B Special Interest Group.

\begin{abstract}
Branding is a well-researched notion in the B2C environment but a concept unexplored in the B2B context. Conceptually, similar to B2C organisations digital communication via digital tools and devices allows B2B organisations experiencing benefits of exposing their brands to a wider audience. In reality questions of whether branding is purposeful in the B2B context and what role digital technologies play in the B2B branding remain open. This study explores branding in the B2B context using Panasonic as a case study, to consider the value of $\mathrm{B} 2 \mathrm{~B}$ branding from the B2B customer (buyer) perspective. Results indicate that $\mathrm{B} 2 \mathrm{~B}$ branding is of importance in the $\mathrm{B} 2 \mathrm{~B}$ context, in particular for an organisation such as Panasonic where reputation is a driving force of attracting new B2B customers and nurturing long-terms relationships with existing B2B customers. Moreover, this study concludes that whilst use of digital technologies enables portraying brand perceptions about Panasonic, digital technologies are yet to be fully embraced for the purpose of branding in the $\mathrm{B} 2 \mathrm{~B}$ context.
\end{abstract}

Keywords: B2B branding; B2B customer; digital technologies; case study method; Panasonic 


\section{Introduction}

In recent years branding played a vital marketing role for business-to-consumer (hereafter, B2C) companies by creating customer loyalty and enhancing a sense of identity for a company or product. The power of branding in building relationship between brands and end-users and maximising financial profitability of a company has clearly been recognised in the consumer research literature (Holbrook, 2014; Tuškej, Golob \& Podnar, 2013). However, the concept of branding has not been fully established in a business-to-business (hereafter, B2B) context (Mudami, 2003; Kuhn, Alpert \& Pope, 2008; Leek \& Christodoulides, 2011; Zahay, Schultz \& Kumar, 2015). Predominantly scholars (Schmitz, 1995; Mudami, 2003; Lynch \& de Chernatony, 2007; Kuhn et al., 2008; Leek \& Christodoulides, 2011) see branding as a challenging or unnecessary task for a B2B business. Hence, definitions and perceptions of the B2B branding term vary among scholars. This in turn prevents any changes in a real world practice (Keränen, Piirainen \& Salminen, 2012; Zahay, Schultz \& Kumar, 2015).

Moreover, with the emergence of digital technologies and, in particular, social media B2B businesses are facing challenges in blindly following 'in vogue' trends and adopting $\mathrm{B} 2 \mathrm{C}$ practices of utilising digital technologies to communicate with customers and other stakeholders - something that conceptually constitute an initial stage of building a brand (Michaelidoua, Siamagkab and Christodoulides, 2011; Kaplan, 2012; Zahay et al., 2015). With this in mind, Zahay et al. (2015) urge scholars to reconsider existing theoretical conceptualisations of $\mathrm{B} 2 \mathrm{~B}$ branding and to understand the practice by undertaking empirical in nature research. Thus, this paper aims to explore B2B branding by, firstly, understanding the $\mathrm{B} 2 \mathrm{~B}$ customers' perspective - in the $\mathrm{B} 2 \mathrm{C}$ context the consumer perspective establishes the presence of the brand in the form of the brand image (Kapferer, 
2012) - (research objective 1; hereafter, RO1) and, secondly, investigating the role of digital technologies in the $\mathrm{B} 2 \mathrm{~B}$ branding (research objective 2; hereafter, $\mathrm{RO} 2$ ).

To address the research aim and objectives we have adopted a phenomenological case study method using Panasonic, the Visual Systems Solutions (hereafter, VSS) division, as a single case. The VSS division is one of five product categories within the B2B sector that Panasonic is involved in, core business of which is selling business projectors and professional displays to a wide array of sectors including education, large venue, rental and staging, transport and retail. The study is carried out in the VSS division within the Panasonic UK branch. Whilst Panasonic is a global brand the importance of branding is paramount for Panasonic in the B2C context (Panasonic, 2015) but not clear in the B2B context. To investigate the $\mathrm{B} 2 \mathrm{~B}$ customer perspective on the $\mathrm{B} 2 \mathrm{~B}$ branding we have conducted in depth semi-structured online interviews with five independent firms, current customers of the Panasonic VSS. Interviewed firms are distinct in terms of their business profiles such as firm size, age, number of employees but all either distribute or supply audiovisual (hereafter, AV) equipment. Moreover, netnographic analysis of the Panasonic digital 'footprint' enabled mapping the Panasonic's B2B branding activities and online presence on digital and social media channels. We have analysed above-mentioned multiple sources of primary and secondary data using predetermined themes which derived from a literature review. Having said that, throughout data collection and analysis process we have remained open to an emergence of new themes.

In line with the B2C studies (Holbrook, 2014; Ohnemus, 2009), this paper indicates that the concept and definition of B2B branding ultimately implies the ways in which a B2B organisation positively influences buying behaviour, confers uniqueness of an organisation and its offering, and reduces the level of perceived risk. Most importantly this paper finds that in the B2B context a combination of both functional and emotional factors are important for a B2B customer (RO1). This result is contrary to the beliefs of majority 
scholars researching B2B branding (Schmitz, 1995; Lynch \& de Chernatony, 2007; Leek \& Christodoulides, 2011) who have claimed that there is no room for emotional factors such as trust in B2B branding. Panasonic's success as a brand stems from their reputation, product quality and personal relationships between personnel and B2B customers. Whilst there may not be empirical evidence of B2B branding as such, these qualities are found to be vital in creating value for the $\mathrm{B} 2 \mathrm{~B}$ brand and to build the reliability and trust that develop brand loyalty. Furthermore, in line with Zahay et al. (2015) this study demonstrates that the salesperson is an important representation of the brand in the $\mathrm{B} 2 \mathrm{~B}$ context, with B2B customers indicating that a faith in individuals working for the B2B brand leads to the faith in the B2B brand. However, results in this paper extend Zahay et al. (2015)'s propositions and illustrate the significance of the salesperson in the B2B brand's identity and image. Additionally, this paper indicate that digital technologies facilitate communication and improves operational process in the B2B context rather than builds the B2B brand (RO2), which is in line with existing conceptual (Michaelidoua et al., 2011; Kaplan, 2012) and empirical (Bolat \& Kooli, 2013) studies. In particular findings of this paper suggest that Panasonic's brand identity was recognisable prior to digitisation. However, Panasonic's B2B customers collectively agree on that with increased customer expectations and less personal interactions prevailing in the $\mathrm{B} 2 \mathrm{~B}$ sector due to digitisation Panasonic's brand image is most likely to be affected. Therefore, digital technologies should be used to manage and maintain the existing B2B brand image and identity.

As most papers adopting a case study method this paper presents contextualised firm specific results which might be different for other B2B organisations, within the same or different industries. Moreover, B2B customers participated in this paper have long-term relationships with Panasonic VSS; hence, novel practices of B2B branding and building rather than maintaining relationships with the $\mathrm{B} 2 \mathrm{~B}$ customer using digital technologies are less likely to emerge. Accordingly, further research exploring other industries and B2B 
settings is paramount for making meaningful conclusions about the value of B2B branding and the role of digital technologies in the $\mathrm{B} 2 \mathrm{~B}$ branding.

This paper is organised as following. Firstly, a review of the current scholarly work identifies gaps in the literature. Secondly, the research method section discusses contextual setting, data collection process and method of data analysis. The research findings section presents integrated results of secondary and primary data analysis. Finally, key conclusions and contribution of this paper follows an extensive discussion of the research findings against the claims and findings of existing published work. Next, the literature review of the current academic studies around B2B branding and the use of digital technologies in the $\mathrm{B} 2 \mathrm{~B}$ context sets the research objectives of this paper.

\section{The Literature Review}

Branding is a concept that is difficult to conceptualise and measure due to its intangible qualities, which are often based on perception, "a brand is a bundle of functional, economic and psychological benefits for the end-user" (Kuhn et al., 2008, p.41). Whilst a business may develop their brand as an asset, branding refers to the science of managing a brand which incorporates a number of different elements that contribute to building an identity for a company (Kapferer, 2012). These elements might be brand values (De Chernatony, 1999), culture (Aaker, 1996; Coleman, de Chernatony \& Christodoulides, 2011) and even the logo and name (Balmer \& Gray 2003; Kapferer, 2012). The importance of branding for a business is paramount in the B2C landscape with businesses utilising elements such as values, culture, logo and name to positively influence a consumer's buying behaviour and enhance differentiation (Gordon, Calantone \& di Benedetto, 1993).

In opposition the concept of branding has not been fully established within the B2B context yet and research has so far been limited due to scepticism into the benefits of branding within the B2B context (Mudami, 2003; Kuhn et al., 2008; Leek \& 
Christodoulides, 2011; Zahay et al., 2015). Predominantly scholars (Schmitz, 1995; Mudami, 2003; Lynch \& de Chernatony, 2007; Kuhn et al., 2008; Leek \& Christodoulides, 2011) argue that branding in the B2B concept is unnecessary. Kuhn et al. (2008, p.41) states, "industrial products do not need branding as it is confusing and adds little value to functional products". Whilst a growing number of scholars (Berry, 2000; Ulaga, 2001; Ulaga \& Eggert, 2006; Keränen et al., 2012; Zahay et al., 2015) stress that branding may not be used in the same way as in the B2C market, especially with B2B services, as they are branded in line with the parent firm rather than the individual product. Ulaga (2001) and Ulaga and Eggert (2006) propose that in the B2B context other elements such as relationships and interpersonal interactions form a B2B brand. Generally literature review around $\mathrm{B} 2 \mathrm{~B}$ branding indicates that definitions and perceptions of the $\mathrm{B} 2 \mathrm{~B}$ branding term vary among scholars and that B2B branding is a very contemporary idea in comparison to B2C branding; therefore there is still much scope for research into its practicality and effectiveness (Keränen et al., 2012).

When discussing branding in general, regardless of the context, the term 'brand equity' defined as " $a$ set of assets and liabilities associated with the brand that add to, or subtract from, the value the product provides" (Aaker, 1996; Keller 2003; Kapferer, 2012) often constitutes the core of branding. In fact in the B2C context brand equity accumulates the following elements such as brand identity, brand meaning, brand response and brand relationships (Keller, 2003; Kapferer, 2012). Kuhn et al. (2008) has concluded that this conceptualisation of the brand equity is applicable in the B2B context; however, such claims were made on a conceptual level with no empirical evidence to support this argument. One of the main elements that comprise the brand equity is the brand identity, responsible for creation of an image in consumers' mind and an association with a product (Keller, 2003). Herein personal perception is vital in influencing buying decisions and process as brands reduce buyers' perceived risk (Keller, 2003; Kapferer, 2012). In the B2B 
context this buying process is not as simple, due to various team members and specialists' involvement (Morris, Berthon \& Pitt, 1999); therefore, initial perceptions of value are created through salespeople or distribution (Leek \& Christodoulides, 2012). Emotional qualities are becoming more important (Leek \& Christodoulides, 2012) in the B2B context through these salespeople, rather than through mass communication and advertisement of the product, which are responsible for brand identity building in the $\mathrm{B} 2 \mathrm{C}$ context (Gordon et al., 1993). In fact, whilst a quality of the product/service and business performance are relevant in both $\mathrm{B} 2 \mathrm{C}$ and $\mathrm{B} 2 \mathrm{~B}$ contexts, in the $\mathrm{B} 2 \mathrm{~B}$ context there is more emphasis on the salespeople as an important brand building strategy (Abratt \& Mofokeng, 2001). Hence, in the B2B context image and identity related associations could be originated from the personalities and values within the salespeople and from experience in purchase situations (Hogg, Carter \& Dunne, 1998). The first assumption, therefore, is that salespeople are essential advocates in the B2B context to portray brand meanings and to build a brand identity.

Moreover, through customer-based brand equity brand relationships are created, and in turn loyalty towards the brand. As the above discussion illustrates, brand relationships are more important in the $\mathrm{B} 2 \mathrm{~B}$ context than in the $\mathrm{B} 2 \mathrm{C}$, due to the relationship with not only the brand but the business, its values and its employees which in turn influences the trust and perception of the product itself (Kuhn et al., 2008). These claims are supported by Lynch and de Chernatony (2004), who add that in the B2B context meaningful relationships in the form of emotional values help to drive competitive advantage. Gilliland \& Johnson (1997) state that feelings such as trust, security and peace of mind represent emotional values that influence B2B customers' decisions. Having said that, for emotional values to be extended to the B2B customer, brand communication is necessary with personal selling being one of the most dominant communication mediums in the B2B context (Hutt \& Speh, 2001). Hence, the skills and characteristics of the sales force play a 
key role in brand communication (Ulrich \& Blut, 2015) and the effectiveness of their communication in sales situations increases the trust and commitment in business relationships (Wren \& Simpson, 1996). Moreover, there has been a change in emphasis towards relationship marketing (Grönroos, 1994; Morgan \& Hunt, 1994) with the use of adaptive selling as a vital technique to form and sustain B2B relationships (Dwyer \& Tanner, 1999).

Relationship marketing has evolved with the development of technology and informationorientated organisations that aim to deliver and communicate quicker and more efficiently (Hunt et al., 2006) with a focus on the customer and effective management of the relationship with them (Tadajewski \& Saren, 2009). Grönroos (1994) highlighted important elements such as promises and trust as cornerstones in building long-term relationships as opposed to short-term transaction orientated exchanges. Promises and trust can be enhanced through expertise, reliability and intentionality. There is evidence of value in building relationships and potential for brand loyalty, which is often seen as more highly regarded than gaining new customers (Garbarino \& Johnson, 1999).

Internal communication is also essential as a means of determining how a brand is conveyed (Baumgarth \& Schmidt, 2010). This is important to streamline and reinforce business values, keeping them consistent amongst employees (Thomson et al., 1999). Internal branding and communication will therefore assist with delivering brand identity.

Finally, in the B2B context longevity of a strong relationship between an organisation and its customers is paramount to the perceived value of the brand. Ravald and Grönroos (1996) suggest that although functional values such as superior product quality and supporting services are important, they are not the most valuable aspects to the B2B customer in a long-term relationship. In long-term relationships a deeper meaning is recognised, through safety, credibility and security. This increases the trust in the B2B business and its values. 
Overall, branding presents many challenges to marketers in the B2B context due to the complex nature of the buying decision process and often perceived outlook that this process is rational and focused on solely functional qualities (Leek \& Christodoulides, 2011; Keränen et al., 2012; Zahay et al., 2015). Moreover, whilst advertising is typically used in the B2C context, it is every so often used as a tool for branding in the B2B context and it is not considered as the main communication path (Lynch \& de Chernatony, 2004). Therefore, the sales force has to be utilised in such a manner to present the correct brand values and messages to the same effect as advertising creates in the B2C context (Ulaga, 2001; Lynch \& de Chernatony, 2004; Ulaga and Eggert, 2006). The question also remains open on whether emotional influence has an impact in the B2B context and if there is a consideration of branding in such context. Whilst functional brand values may dominate B2C purchase situations, these are influenced by emotional considerations such as trust, security and peace of mind in the B2B context (Schmitz, 1995; Lynch \& de Chernatony, 2007). Altogether above listed challenges have so far limited understanding into whether or not B2B branding is important for businesses.

However, with the recent emergence and surge of digital technologies an additional branding opportunity has developed for B2B businesses (Zahay et al., 2015). Adding to the previous discussion of the importance of the relationship marketing for the B2B branding, the study by Chelariu \& Osmonbekov (2014) concludes that information communication technology enables more timely market information and trust-based ties between the business partners. Such factors have a considerable impact on communication richness and are relevant in the building and maintaining of long-term and successful business relationships (Chelariu \& Osmonbekov, 2014).

Few studies conclude on an increased productivity and B2B customer satisfaction with new information and communication technologies such as mobile technology and emails enabling speed and efficiency in the buying process (Brennan and Croft, 2012; Bolat and 
Kooli, 2013). However the question remains open on whether such speed and efficiency associated with the use of digital technologies contributes to the $\mathrm{B} 2 \mathrm{~B}$ branding. Furthermore, with further digitisation there has been a change in dynamics between the customer and the business (Rowley, 2004). In particular, Brennan and Croft (2012) and Bolat and Kooli (2013) suggest that social media/networks can be utilised as a vehicle for soft marketing through B2B relationship and brand development. However, such claims are not fully supported by empirical evidence.

To conclude, this section identifies the following aspects to be studied empirically, (1) an understanding of the B2B branding from B2B customers' perspective with particular focus on what constitute brand associations and image and the role of salespeople in building such associations (RO1); (2) the role of digital technologies in the $\mathrm{B} 2 \mathrm{~B}$ branding (RO2).

\section{Research Methodology}

To address the research objectives, identified in the previous section, we have adopted a phenomenological case study method (Creswell, 2013; Yin, 2014) using Panasonic, the Visual Systems Solutions (hereafter, VSS) division, as a single case. Panasonic is a Japanese multinational electronics corporation, with hundreds of products in multiple markets across both B2C and B2B sectors (Panasonic, 2015). Whilst Panasonic is a global brand the importance of branding is paramount for Panasonic in the B2C context (Panasonic, 2015) but not clear in the B2B context. The VSS division is one of five product categories within the $\mathrm{B} 2 \mathrm{~B}$ sector that Panasonic is involved in, the core business of which is selling business projectors and professional displays to a wide array of sectors including education, large venue, rental and staging, transport and retail (Panasonic Visual Systems Solutions, 2015). The study is a single-country research carried out in the VSS division within the Panasonic UK branch. 
To investigate the $\mathrm{B} 2 \mathrm{~B}$ customer perspective on the $\mathrm{B} 2 \mathrm{~B}$ branding we have conducted in depth semi-structured interviews with sales managers, marketing managers and managing directors across five independent firms, current customers of the Panasonic VSS. The interviewed firms are distinct in terms of their business profiles such as firm size, age, number of employees but all either distribute or supply AV equipment (see Table 1). 
Table 1 - Panasonic VSS Customers' profile

Identification code /

Profile

abbreviation allocated

\section{UAVB}

A supplier and integrator of AV equipment on a B2B basis. For 25 years the company has specialised in the sale, hire and installation of video and computer display systems.

SAVB

Its core business is in the design and implementation of icon spaces from an AV perspective. This includes museums and galleries, sports stadiums, racecourses, music venues and corporate spaces.

SVB

A family run business specialising in integration of AV. It has been in business approximately for 30 years. Core business is an integration of projection, flat panel displays, video conferencing, audio conferencing and room control systems.

SOB A distributor of $\mathrm{AV}$, print and imaging equipment that in addition provides the following services, servicing AV, IT reselling and managing office supply channels.

SB A national supplier of integrated AU systems and communications technology. It provides all aspects of $\mathrm{AU}$ integration from consultancy and design to the supply, installation and on-going maintenance of AV equipment. 
With consideration of the time limitations in $\mathrm{B} 2 \mathrm{~B}$ organisations online interviews were used as the primary data collection method due to the value and focus on personal language as data in an attempt to improve understanding of the social and culture phenomena and processes rather than to make generalisations of populations (Brinkmann \& Kvale, 2014). The data collected in interviews reflects a much more personal approach, where the participant may be more inclined to indulge in certain information and opinions which may not have been discovered from focus groups or face to face interviews. Email interviewing was chosen as the medium for the qualitative research due to its cost, efficiency and accessibility for both the interviewer and interviewees (Meho, 2006). This medium employs an asynchronous mode for interviewing, offering a method which generates richer, more thoughtful data for analysis and opportunity for reflection for the participants who can construct their own experiences through their dialogue (Hewson \& Laurent, 2008). There also remains the potential for further questions in response to answers and themes that may be uncovered which had not already been thought of.

We analysed the interview data using a thematic analysis approach, firstly, pursuing the examination of textual elements such as words, phrases, sentences, or paragraphs; secondly, coding data by relating it predetermined themes (see Table 2) or recognising new emerging themes in order to come up with a meaning or label for categories and sub-categories that illustrate regularities, relationships and patterns within the data, which are useful when readdressing the research objectives (Braun \& Clarke, 2006). Moreover, memoing assisted the data analysis process by clarifying and articulating assumptions around possible links and relationships. 


\section{Table 2. Interview Scenario}

\begin{tabular}{|c|c|}
\hline Q1* & $\begin{array}{l}\text { Please tell me a bit about the organisation you work for and your role within } \\
\text { company? }\end{array}$ \\
\hline & $\begin{array}{l}\text { eme - Role of Digital Technologies } \\
\text { : Speed and Efficiency of Communication and Role of Salesperson }\end{array}$ \\
\hline $\begin{array}{l}\text { Q2 } \\
\text { Q3 }\end{array}$ & $\begin{array}{l}\text { What digital technologies does your organisation use? } \\
\text { How has digitisation/the introduction of digital technologies (mob } \\
\text { communication, email, internet, online marketing/promotional software, soc } \\
\text { media, after sales support systems, sales admin etc.) been utilised by yc } \\
\text { organisation? And how has it affected your day-to-day job, if it has at all? }\end{array}$ \\
\hline Q4 & $\begin{array}{l}\text { Do you think Panasonic VSS utilise their digital technologies effectively } \\
\text { communicate with customers? (Product info, events, social media)? In your opinio } \\
\text { is this important in a B2B environment? }\end{array}$ \\
\hline Q5 & $\begin{array}{l}\text { Does speed and efficiency in communication affect how you perceive Panasonic } \\
\text { a brand? Speed and efficiency of communication are often linked to digitisati } \\
\text { can you tell me a bit about how this has affected your organisation? How impor } \\
\text { is this in relation to a brand's image and identity? (Linkage to Brand Identity) }\end{array}$ \\
\hline Q6 & $\begin{array}{l}\text { How has the development/introduction of digital technologies influenced how } \\
\text { perceive Panasonic as a brand, in terms of the values and beliefs that you associ } \\
\text { with them? (Linkage to Brand Identity) }\end{array}$ \\
\hline & $\begin{array}{l}\text { How has your relationship with the sales person been affected by digita } \\
\text { technologies? }\end{array}$ \\
\hline
\end{tabular}

\section{Part III: Theme - Brand Identity}

Q8 Can you please tell me your first impressions of Panasonic and VSS as a brand?

Q9 What is your current opinion of Panasonic and VSS as a brand?

Q10 In what ways do Panasonic VSS appeal to their customers?

Q11 In as much detail as possible, how do you think Panasonic VSS build their brand identity?

\section{Theme IV: Theme - Brand Relationships}

Sub-themes: Trust and Role of Salesperson
Q12 Brand relationships are often important for brands to be successful, what is your relationship with Panasonic VSS like?
Q13 How has your relationship with Panasonic VSS been affected by digital technologies? How are these relationships maintained between Panasonic VSS and your organisation?
Q14 Is branding in the B2B context as important to your organisation as it may be in the B2C (business to consumer) context?
Q15 Is trust important to you in a brand relationship?
Q16 How do Panasonic develop trust between themselves and your organisation?
Q17 With the sales person one way for Panasonic to communicate with you as a customer, how influential are they in representing Panasonic as a brand?

\section{Theme V: Theme - Brand Associations}

Q18 Are there specific values and brand associations that come to mind when you think

of Panasonic?

Q19 Do Panasonic VSS use brand associations (logo, name, slogan) when sending out

emails and marketing/promotional material?

Q20 What effect does this have on you as a customer?

Theme VI: Theme - Brand Loyalty

Q22 Are you loyal to Panasonic as a brand? If so, why? 
With a key condition of a case study research being the need for multiple sources of data (Yin, 2014), we collected secondary data on the usage of digital technologies by Panasonic VSS. Considering the ease of accessing information online and organisations using the internet as a means of communication (Kozinets, 2010), we engaged in the netnographic research (an online marketing research approach assisting in analysis of digital data represented by social interactions and analytical information of digital users' engagement) to conduct a digital 'footprint' on Panasonic VSS as a brand. We adopted Tuten and Solomon (2013) definition and conceptualisation of a digital 'footprint', according to which a digital 'footprint' represents a map of an individual's or company's activities and engagement with social media digital channels, clarifying the purpose of such activities and engagement across four possible social media zones, namely, social community (zone 1), social publishing (zone 2), social commerce (zone 3) and social entertainment (zone 4). The next section displays integrated results of the thematic and netnographic analysis.

\section{Research Findings}

This section illustrates results of data analysis across multiple sources of data, interview transcripts and secondary analysis of the Panasonic VSS's digital 'footprint'. The following themes have been identified, (1) branding in B2B; (2) brand image; (3) brand identity; (4) brand relationship; (5) role of salesperson; (6) brand communication; (7) brand loyalty; and (8) use of digital technologies. First each theme is discussed separately and the overall conclusion is presented next.

\section{(1) Branding in $B 2 B$}

Four out of five B2B customers of Panasonic VSS see B2B branding as just as important as branding in the $\mathrm{B} 2 \mathrm{C}$ context, with one $\mathrm{B} 2 \mathrm{~B}$ customer stressing that only product and service matters in the $\mathrm{B} 2 \mathrm{~B}$ context rather than brand name: 
No, as the B2B consumer we are uninterested in the brand as long as what we buy works and looks amazing. (SAV)

In comparison to branding in the $\mathrm{B} 2 \mathrm{C}$ context where brand associations are related to the name, logo, marketing and advertising, the B2B brand constitutes different elements such a reputation, support and promotion through $\mathrm{B} 2 \mathrm{~B}$ relationships:

Yes just as important in $B 2 B$, reputation is key. (SB)

Yes, however, $B 2 B$ is more about having the support and performance from the supplier. $(S O B)$

Definitely because the $B 2 B$ relationship enables Panasonic to be promoted through their business partners. (SVB)

For a brand such as Panasonic having a positive reputation enables a promotion through different channels and, as a result, B2B customers even hold a sense of pride in being part of such relationship. Sales manager from UAVB emphasises:

Yes, the Panasonic brand carries a lot of weight with us. As a company we are proud to be associated with Panasonic. (UAVB)

\section{(2) Brand image}

Conceptually brand image incorporates "perceptions about a brand that are reflected by brand associations held in a consumer's memory" (Keller, 1993, p.3). Through a positive perception, consumers are more likely to buy into the brand. In this study, brand associations, such as reliability, product quality and support were identified as a significant contributor to brand image in the B2B context:

For me it conjures up an image of being reliable, globally recognised, technologically advanced, well made and intuitive technology. (UAVB) 
Panasonic are like a dearly loved grandfather, solid and honest. (SAVB)

Quality, reliability and support are values I associate with Panasonic and are factors that we seek in a B2B brand. (SAVB)

Consistency across all five $\mathrm{B} 2 \mathrm{~B}$ customers as found in the brand associations that $\mathrm{B} 2 \mathrm{~B}$ customers held with Panasonic VSS. Reliability was identified by most of the customers as a major positive of Panasonic VSS as a brand, through good product quality and support from personnel that work within the division. The factors of quality, support and reliability were considered as important considerations that customers seek in a B2B relationship.

With the aim to explore the role of using digital technologies in the B2B branding, this study finds that the speed and efficiency of communication plays a positive and significant role in how a brand is perceived in the B2B context. Speed and efficiency of communication between the $\mathrm{B} 2 \mathrm{~B}$ brand and the $\mathrm{B} 2 \mathrm{~B}$ customer is viewed as an important element of a B2B relationship as it helps to improve the business transaction process and allows information to be transferred faster to clients:

It is definitely one element that impacts how they are perceived but there are other elements such as their good after sales service, product quality etc. that are also just as important. (SB)

With the clients we deal with - time is everything. They expect responses instantaneously. To this end, Panasonic have been exceptional with their response times and support. (SVB)

Moreover, sales manager from UAVB also emphasised that in the Panasonic VSS, the VSS sub-brand holds nothing more than the identification of the products that the division sells. Whereas the main brand name, Panasonic, has major appeal in the B2B context. All B2B 
customers recognise the Panasonic name and buy/recommend the brand for that reason alone:

People will buy Panasonic based on the name alone. The VSS brand is lost against the Panasonic brand and in my opinion does not carry much significance. (UAVB)

\section{(3) Brand identity}

Whereas brand image concerns the perception of the customer about the brand, brand identity regards how a brand wants to be perceived. Brand associations can be utilised in order to position a brand. This study finds that all five B2B customers recognise that Panasonic VSS has built their brand identity over many years and relate the strong brand identity to exceptional quality of its products, which helped the Panasonic VSS to position itself as a reliable and reputable brand. Through such brand associations as competitive and reasonable pricing, B2B customer have kept faith in the brand:

If Panasonic weren't trusted with sensitive information then equally we wouldn't use that brand. If we found out our pricing wasn't competitive that would also lead to loosing trust. (SAVB)

The Panasonic VSS customers also highlighted that digitisation helps to enhance and reinforce brand values and brand identity; however, there was greater emphasis on how brand identity existed before the introduction of digital technologies. Whilst there is a recognition that digital technologies can assist in creating brand identity, a brand such as Panasonic VSS, who were around before digitisation, relies less on these for building brand identity. Managing director from SB states:

It has reinforced values that we already associated with Panasonic, as they have been a brand around for many years. I think other organisations that are new and have grown with digital technologies rely on this a lot more. 
A concern that became evident regarding the brand identity was the confusion in the difference between Panasonic and VSS and whether they hold the same identity or whether they are different therefore possessing different values. Most B2B customers regarded the two as the same, with the VSS brand not being as strong as Panasonic. Sales manager from UAVB urges this could create mixed messages and confusion with new customers:

But I don't see the Panasonic VSS brand as being that strong. Hit the website and we see the name Panasonic, but no obvious mention of VSS. Again, with the emails, Panasonic is on the header, but not always VSS. This can tend to send out a mixed message. (UAVB)

\section{(4) Brand Relationships}

Throughout above display of results, it has been pointed several times that relationship between $\mathrm{B} 2 \mathrm{~B}$ customer and $\mathrm{B} 2 \mathrm{~B}$ brand are key to the B2B branding in the Panasonic VSS case. In addition this study find that trust is valued by all five B2B customers as an important attribute of a successful brand relationship with many reiterating that without trust there would be no confidence in the Panasonic VSS brand. B2B customers collectively agree that the Panasonic VSS has built this trust through their personnel, reliable products and efficiency of communication. Moreover, it has been pointed across all customers that such brand relationships with the Panasonic VSS will continue to be strong as long as there is trust between the customer and the brand.

In particular, B2B customers also stressed the importance of personal relationships in their brand relationship with Panasonic VSS and that the personal nature of these relationships helps to maintain their business relationships. There was a general consensus across all five B2B customers that these personal relationships are one of the major factors in having a strong brand relationship with Panasonic VSS: 
We feel more inclined to buy the brand because of the personal relationships that have been built. (SOB)

Through many years of working with Panasonic I have built up a strong passion for the brand with many relationships with people that work there. (SB)

\section{(5) Role of Salesperson}

In this study the salesperson was found to have many purposes in the B2B context. Firstly salespeeople are the main point of contact between the Panasonic VSS and the B2B customer, to keep them updated with product information, news, pricing and additional support services. Salespeople are, therefore, the most important means of brand communication for the Panasonic VSS brand. Secondly, B2B customers expressed the importance of the salesperson in creating and enhancing a positive brand image for the Panasonic VSS. The salesperson is representative of the brand especially as the primary means of communication and is recognised as holding the same values as the B2B brand. Sales and marketing director from SAVB, however, did convey their concern about completely blaming a brand for something a salesperson may have done wrong:

We didn't have the problem of waiting for responses with our old account manager so that makes me think it comes down to the individual representing the organisation rather than just the organisation itself.

Thirdly, the salesperson maximises a brand resonance, discussed previously, for the Panasonic VSS through the regular personal contact, acting as a promotional tool and keeping the Panasonic VSS brand at the forefront of customers' minds. Lastly, support from the salesperson helps to maintain a strong brand relationship with all five B2B customers agreeing on that their personal relationship with the salesperson is key to Panasonic's success. Results of this study emphasise a substantial role of the salesperson in the $\mathrm{B} 2 \mathrm{~B}$ branding. 


\section{(6) Brand Communication}

All five B2B customers agreed that brand communication is imperative in the B2B context, in informing customer about new products and technologies. With the complexity of the distribution channels, where system integrators and distributors are involved, the transfer of information is vital. Brand communication was also found to have a further purpose of reiterating the brand message and that personal interaction is often a way of communicating this:

VSS also use banners in emails to communicate new products/events in emails that are focused on the VSS division. These reiterate the Panasonic brand and the products. $(S B)$

However, there were mixed opinions on how well Panasonic VSS communicate via digital technologies. Majority (three out of five) customers (UAVB, SOB, SB) stated that they do receive email newsletters and specific emails regarding upcoming events and that employees use specific VSS banners in their emails to highlight new products. Social media is one area that B2B customers identified as lacking in communication and engagement. In fact, this is in line with the digital 'footprint' analysis, results of which are presented later in this section.

\section{(7) Brand Loyalty}

Brand loyalty towards the Panasonic VSS was very conclusive among all five B2B customers. In particular, customers underlined how the people involved in the VSS division offer a continued support and value the relationships that they have built with them as customers. Moreover, all customers illustrated that Panasonic have also been loyal to them as an individual and customer, demonstrating the interrelationship that occurs between supplier and buyer: 
Loyalty is created by people and it is the people who have worked with Panasonic (both past and present) that have had more to do with my company and me as an individual sales person staying loyal to Panasonic. (UAVB)

Product quality and customer service were other reasons for brand loyalty that B2B customers identified, with products that work financially a major decider in choice of brand. In addition, it was made evident that although buyers may be loyal to the brand, the choice of product in a transaction ultimately depends on the specifications of the end user, "there are occasions where our end user specifically requests a different brand" (SVB).

This highlights the complexity of a B2B relationship, which in turn complicate branding in the B2B context.

\section{(8) Use of Digital Technologies}

Display of previous results clearly indicates that digital technologies play a particular role in the $\mathrm{B} 2 \mathrm{~B}$ branding. In particular, the overriding response from B2B customers emphasised the importance of digital technologies in enhancing and improving communication between $\mathrm{B} 2 \mathrm{~B}$ customers and the $\mathrm{B} 2 \mathrm{~B}$ brand through mobile and email communication. As a result, the speed and efficiency has allowed organisations to become more flexible and dynamic which has improved the overall business performance. This is due to transfer of information and business transactions being completed faster. However, the speed and efficiency is also causing an increase in customer expectations as B2B customers are expecting faster response times and efficient business conduct, "it has enabled speed and efficiency except now everyone wants everything done immediately" $(S A V B)$.

In terms of mass communication, digital technologies were also recognised as a means of promoting a brand to a wider audience and transforming the way brands communicate with customers. However, there was recognition that currently brands in B2B and specifically 
Panasonic VSS do not utilise this as much as they could and in the B2B context it is not a main purpose of digital technologies.

Moreover, in this study B2B customers also discussed in details the impact of digital technologies on personal relationships. Digital technologies are considered important in facilitating communication but there is often an overreliance on these new means of interaction:

This is sometimes a negative, as there is less face-to-face interaction and therefore we can become too reliant on these digital technologies in our personal relationships with Panasonic employees. (SOB)

As it has been revealed previously in this section, the Panasonic VSS customers state that personal relationships existed prior to digitisation and having digital technologies an new means of interaction is often a negative for the relationship, where there is less face-to-face communication and personal selling.

In addition to interviews' data we have conducted a digital 'footprint' analysis (see Table 3) for the Panasonic VSS, which helps to complete a whole picture of social media activities the B2B brand (Panasonic VSS) engaged with and how that is perceived by B2B customer. 
Table 3 - Digital Footprint (after Tuten and Solomon, 2013)

\begin{tabular}{|c|c|}
\hline $\begin{array}{l}\text { Zone } 1 \text { - Social } \\
\text { Community }\end{array}$ & $\begin{array}{l}\text { Panasonic VSS have their own personal Facebook profile } \\
\text { (https://www.facebook.com/PanasonicVisualSolutionsEU), which is used to } \\
\text { communicate relevant product information, event information or news associated } \\
\text { with the division and has been utilised as communication of brand information } \\
\text { rather than customer interaction. This profile, however, is a European based } \\
\text { profile for the entirety of the VSS division and a UK profile specifically does not } \\
\text { exist. The posts to this profile are quite irregular and consumption seems to be } \\
\text { lacking (Tuten and Solomon 2014) with limited feedback from customers or } \\
\text { 'likes' of the profile. } \\
\text { Within the Panasonic VSS section of the Panasonic Business website } \\
\text { (http://business.panasonic.co.uk/visual-system/) there is a 'community' area } \\
\text { highlighting the different means of communication with the division through } \\
\text { social media. Other areas on the website also offer brand communication through } \\
\text { division news, product updates, after sales support services and further } \\
\text { information regarding the VSS division. }\end{array}$ \\
\hline $\begin{array}{l}\text { Zone } 2 \text { - Social } \\
\text { Publishing }\end{array}$ & $\begin{array}{l}\text { Panasonic VSS utilises Facebook as a means of publishing content. In addition, } \\
\text { Panasonic VSS have a Twitter profile (@ PanasonicVisual) but this too is limited } \\
\text { in content and reach (few followers) compared to a number of followers for the } \\
\text { main brand's Twitter account. Twitter profile again has not been utilised as a } \\
\text { medium of communication between the brand and customers but more as a } \\
\text { platform for promoting news and content through links to external pages, } \\
\text { YouTube or the Panasonic website. } \\
\text { The irregularity of posts is also evident again with months between posts on some } \\
\text { occasions. Panasonic VSS is also a contributor to the Panasonic Business } \\
\text { YouTube channel (https://www.youtube.com/user/PanasonicBusiness), which } \\
\text { covers all B2B divisions across Europe, with designated areas for each product } \\
\text { division. Content updated for the VSS is much more regular here than on other } \\
\text { social media sites. }\end{array}$ \\
\hline $\begin{array}{l}\text { Zone } 3 \text { - Social } \\
\text { Commerce }\end{array}$ & $\begin{array}{l}\text { Currently Panasonic VSS offers little in the way of social entertainment online. } \\
\text { However, this is representative of Panasonic as a brand with the Panasonic UK } \\
\text { Facebook and Twitter profiles also offering little in the way of entertainment, } \\
\text { apart from the occasional competition where Panasonic products are offered as } \\
\text { prizes. In terms of gaming or game based marketing there is no offering. }\end{array}$ \\
\hline $\begin{array}{l}\text { Zone } 4 \text { - Social } \\
\text { Entertainment }\end{array}$ & $\begin{array}{l}\text { For Panasonic VSS, this concept in the B2B environment is yet to fully exist, } \\
\text { with a lack of interaction on the social media platforms and the lack of an e- } \\
\text { commerce site for business products. }\end{array}$ \\
\hline
\end{tabular}


In line with the B2B customers' views, the digital 'footprint' analysis concludes that the Panasonic VSS is behind in embracing social media, in particular. This is primarily to difficulty of separating own B2B sub-brand from the main Panasonic brand and its online presence. Nevertheless, B2B customers conclude that an increased involvement of the Panasonic VSS with social media communication will not lead to building a stronger B2B brand image among customers. It is personal relationships and brand relationships in general that ground the $\mathrm{B} 2 \mathrm{~B}$ branding. Whereas social media is a communication medium to raise profile of the Panasonic VSS brand among a wider audience.

In summary, findings in this paper suggest that branding exists in the B2B context and that, most importantly, building brand identity is a process happening over time and is linked to various elements such as brand associations (reliability, product quality), brand relationships (in particular relationships with the salesperson) that assist in building B2B brand identity. Moreover, findings in this paper reveal that the introduction of digital technologies has certainly improved business performance through the speed and efficiency associated with it, and although digitisation has certainly helped to enhance the Panasonic VSS brand identity, it was established prior to digitisation. Hence, digital technologies have only reinforced brand values that B2B customers associated with the Panasonic brand. Next section reflects on main findings of this paper against existing literature.

\section{Discussion}

This chapter discusses the implementations and analysis of the findings in accordance with the two objectives set out in the introduction.

In line with the B2C studies (Holbrook, 2014; Ohnemus, 2009), this paper indicates that the concept and definition of B2B branding ultimately implies the ways in which a B2B organisation positively influences buying behaviour, confers uniqueness of an organisation 
and its offering, and reduces the level of perceived risk. However, research findings in this paper clarifies that the process of branding and building brand identity in the B2B context is very much different to the $\mathrm{B} 2 \mathrm{C}$ context. Whereas branding in the $\mathrm{B} 2 \mathrm{C}$ is often focused around the individual product, the concept of branding in the B2B is aligned with the organisation instead. This is line with Berry (2000) who claimed that B2B branding involves different factors impacting and affecting a B2B brand's identity. Most importantly this paper finds that in the B2B context a combination of both functional and emotional factors are important for a $\mathrm{B} 2 \mathrm{~B}$ customer (RO1). This result is contrary to the beliefs of majority scholars researching B2B branding (Schmitz, 1995; Lynch \& de Chernatony, 2007; Leek \& Christodoulides, 2011) who have claimed that there is no room for emotional factors such as trust in B2B branding. Panasonic's success as a brand stems from their reputation, product quality and personal relationships between personnel and B2B customers. Whilst there may not be empirical evidence of B2B branding as such, these qualities are found to be vital in creating value for the B2B brand and to build the reliability and trust that develop brand loyalty. As findings of this paper show that B2B branding is emphasised by the majority of B2B customers of a global organisation such as Panasonic that holds great value in their brand name and strong reputation (Lilien \& Grewal, 2012). In future research it will be essential to consider smaller B2B organisations and explore branding for such organisations that do not have the same reputation and identity as Panasonic.

Furthermore, in line with Ulla and Eggert (2006) and Zahay et al. (2015) this study demonstrates that the salesperson is an important representation of the brand in the B2B context, with B2B customers indicating that a faith in individuals working for the B2B brand leads to the faith in the B2B brand. However, results in this paper extend Zahay et al. (2015)'s propositions and illustrate the significance of the salesperson in the B2B brand's identity and image. In this study personal relationships are viewed by B2B customers as 
one of the major influences on brand image with long-term relationships being key to Panasonic's success and with the salesperson being identified as the main employee within Panasonic with whom customers a personal relationship. Whilst emotional qualities such as trust were recognised as key advantages and occurred as a result of personal relationships (Groonroos, 1994; Gilliland \& Johnson, 1997; Keller, 2003; Lynch \& de Chernatony, 2007), other qualities such as support and reliability were vital for B2B buyers in their loyalty with Panasonic. Reliability was recognised in the literature review section as a potential positive brand association. However, support was highlighted in the findings suggesting that strong $\mathrm{B} 2 \mathrm{~B}$ relationships are a result of an interrelationship between the customer and a B2B brand where working in partnership is becoming more prominent (Bettencourt, Blocker, Houston \& Flint, 2015). In addition, this paper's findings demonstrate that as the main communication between Panasonic and their customers, the salesperson is imperative in conveying the brand's values and identity. This is line with Mudambi (2002) who suggests that the sales force has a key role to play in brand communication. Although Panasonic's brand communication in other areas of the business is significant, especially via digital technologies, within the VSS division it is severely lacking and, therefore, there is heavy reliance on the salesperson. In addition, salespeople were identified as the main source of trust in the relationship between Panasonic and B2B customer. Srinivasan and Srivastava (2012) report similar findings. Hence, salespeople are crucial in representing the $\mathrm{B} 2 \mathrm{~B}$ brand, as a form of communication, identity and establishing and maintaining long-term relationships with B2B customers.

Additionally, this paper indicate that digital technologies facilitate communication and improves operational process in the $\mathrm{B} 2 \mathrm{~B}$ context rather than builds the $\mathrm{B} 2 \mathrm{~B}$ brand $(\mathrm{RO} 2)$, which is in line with existing conceptual (Michaelidoua et al., 2011; Kaplan, 2012) and empirical (Bolat \& Kooli, 2013) studies. In this paper findings show that B2B customers expressed the importance of speed and efficiency of communication enabled by digital 
technologies on their perception and brand image of Panasonic, underlining the improvements this has made to their overall business transactions. The use of digital technologies is recognised by this study as an additional means of influencing a customers' perception of a B2B brand. Fundamentally, however, the brand identity that Panasonic has built up over many years remains consistent and, although the use of digital technologies may influence a brand's image, it does not change the core values of the brand that existed prior. In addition, the improved performance as a result has led to increased customer expectations, which may have a negative effect on the brand if not managed correctly. A vital function of digital technologies in the B2B context is a brand communication. Netnographic analysis and B2B customers are in agreement that digital technologies are a means of communicating the Panasonic B2B brand to a mass audience, hence, are still important in enhancing a B2B brand image and recognition.

\section{Conclusions and Recommendations}

In line with the B2C studies (Holbrook, 2014; Ohnemus, 2009), this paper indicates that the concept and definition of B2B branding ultimately implies the ways in which a B2B organisation positively influences buying behaviour, confers uniqueness of an organisation and its offering, and reduces the level of perceived risk. Most importantly this paper finds that in the $\mathrm{B} 2 \mathrm{~B}$ context a combination of both functional and emotional factors are important for a $\mathrm{B} 2 \mathrm{~B}$ customer (RO1). This result is contrary to the beliefs of majority scholars researching B2B branding (Schmitz, 1995; Lynch \& de Chernatony, 2007; Leek \& Christodoulides, 2011) who have claimed that there is no room for emotional factors such as trust in B2B branding. Panasonic's success as a brand stems from their reputation, product quality and personal relationships between personnel and B2B customers. Whilst there may not be empirical evidence of $\mathrm{B} 2 \mathrm{~B}$ branding as such, these qualities are found to 
be vital in creating value for the B2B brand and to build the reliability and trust that develop brand loyalty. Furthermore, in line with Zahay et al. (2015) this study demonstrates that the salesperson is an important representation of the brand in the $\mathrm{B} 2 \mathrm{~B}$ context, with $\mathrm{B} 2 \mathrm{~B}$ customers indicating that a faith in individuals working for the $\mathrm{B} 2 \mathrm{~B}$ brand leads to the faith in the B2B brand. However, results in this paper extend Zahay et al. (2015)'s propositions and illustrate the significance of the salesperson in the B2B brand's identity and image. Additionally, this paper indicate that digital technologies facilitate communication and improves operational process in the B2B context rather than builds the B2B brand (RO2), which is in line with existing conceptual (Michaelidoua et al., 2011; Kaplan, 2012) and empirical (Bolat \& Kooli, 2013) studies. In particular findings of this paper suggest that Panasonic's brand identity was recognisable prior to digitisation. However, Panasonic's B2B customers collectively agree on that with increased customer expectations and less personal interactions prevailing in the $\mathrm{B} 2 \mathrm{~B}$ sector due to digitisation Panasonic's brand image is most likely to be affected. Therefore, digital technologies should be used to manage and maintain the existing B2B brand image and identity.

As most papers adopting a case study method this paper presents contextualised firm specific results, which might be different for other B2B organisations, within the same or different industries. Moreover, B2B customers participated in this paper have long-term relationships with Panasonic VSS; hence, novel practices of B2B branding and building rather than maintaining relationships with the B2B customer via digital technologies are less likely to emerge. Accordingly, further research exploring other industries and B2B settings is paramount for making meaningful conclusions about the value of B2B branding and the role of digital technologies in the B2B branding. Finally, it is critical to recognise and study the B2B branding from a wider audience's perspective and how effective digital technologies are in raising profile of brands beyond the B2B customers circle; hence, maximising a B2B brand equity. Hence, a possible area for further research is the use of 
social media by B2B organisations across industries as opposed to early-adopters and prevailing users of social media, creative B2B firms, studied by Bolat and Kooli (2013) to see the impact it has on their brand image and whether this affects buying behaviour in the B2B environment. 


\section{References}

Aaker, D.A. (1996). Building Strong Brands. New York: Free Press.

Abratt, R. \& Mofokeng, T.N. (2001). Development and management of corporate image in South Africa. European Journal of Marketing, 35, 368-386.

Balmer, J.M.T. \& Gray, E.R. (2003). Corporate brands: what are they? What of them? European Journal of Marketing, 37, 972-997.

Baumgarth, C. \& Schmidt, M. (2010). How strong is the business-to-business brand in the workforce? An empirically-tested model of 'internal brand equity' in a businessto-business setting. Industrial Marketing Management, 39, 1250-1260.

Berry, L.L. (2000). Cultivating service brand equity. Journal of the Academy of Marketing Science, 28, 128-137.

Bettencourt, L.A., Blocker, C.P., Houston, M.B. \& Flint, D.J. (2015). Rethinking customer relationships. Business Horizons, 58, 99-108.

Birks, M., Chapman, Y. \& Francis, K. (2008). Memoing in qualitative research. Journal of Research in Nursing, New York: SAGE.

Bolat, E., \& Kooli, K. (2013). Mobile Social Media as a Strategic Capability: Expanding Opportunties Social Media Has to Offer to B2B Firms. In: Academy of Marketing, 9-11 July 2013, Cardiff.

Braun, V. \& Clarke, V. (2006). Using thematic analysis in psychology. Qualitative Research in Psychology, 3, 77-101.

Brennan, R. \& Croft, R. (2012). The use of social media in B2B marketing and branding: An exploratory study. Journal of Customer Behaviour, 11, 101-115. 
Brink, P.J. (1991). Issues of reliability and validity. In: Morse, J.M. Qualitative nursing research: A contemporary dialogue (164-186). Newbury Park, CA: SAGE.

Brinkmann, S. \& Kvale, S. (2014). InterViews - Learning the Craft of Qualitative Research Interviewing. $3^{\text {rd }}$ ed. New York: SAGE.

Bryman, A. \& Bell, E. (2011). Business Research Methods. Oxford: OUP Oxford.

Chelariu, C. \& Osmonbekov, T. (2014). Communication technology in international business-to-business relationships. Journal of Business \& Industrial Marketing [online], 29, 24-33.

Coleman, D., de Chernatony, L. \& Christodoulides, G. (2011). B2B service brand identity: Scale development and validation. Industrial Marketing Management, 40, 1063 1071.

Crabtree, B.F. \& Miller, W.L. (1999). Doing Qualitative Research. $2^{\text {nd }}$ ed. New York: SAGE.

Creswell, J.W. (2013). Qualitative Inquiry and Research Design. $3^{\text {rd }}$ ed. New York: SAGE.

de Chernatony, L. (1999). Brand management through narrowing the gap between brand identity and brand reputation. Journal of Marketing Management, 15, 157-179.

Dwyer, F.R. \& Tanner, J.F.Jr. (1999). Business Marketing Connecting Strategy, Relationships and Learning. New York: McGraw-Hill.

Garbarino, E. \& Johnson, M.S. (1999). The Different Roles of Satisfaction, Trust and Commitment in Customer Relationships. Journal of Marketing, 63, 70-87.

Gilliland, D.I \& Johnston, W.J. (1997). Towards a model of business-to-business marketing communications effects. Industrial Marketing Management, 26, 15-29. 
Gordon, G.L., Calantone, R.J. \& di Benedetto, C.A. (1993). Brand Equity in the Businessto-Business Sector: An Exploratory Study. Journal of Product and Brand Management, 2, 4-16.

Grönroos, C. (1994). From marketing mix to relationship marketing: towards a paradigm shift in marketing. Management Decision, 32, 4-20.

Hewson, C. \& Laurent, D. (2008). Research Design and Tools for Internet Research. In: Fielding, N., Lee, R. \& Blank, G. The Sage Handbook of Online Research Methods. London: SAGE.

Hogg, G., Carter, S. \& Dunne, A. (1998). Investigating the links between a corporate brand and a customer brand. Journal of Brand Management, 14, 879-895.

Holbrook, M. B. (2014). The consumer perspective on branding. Brands: Interdisciplinary Perspectives, 19, 297.

Hunt, S.D., Arnett, D.B. \& Madhavaram, S. (2006). The explanatory foundations of relationship marketing theory. Journal of Business \& Industrial Marketing, 21, $72-87$.

Hutt, M.D. \& Speh, T.W. (1998). Business Marketing Management: A Strategic View of Industrial and Organisational Markets. Fort Worth: Dryden Press.

James, J. (2002). Information Technology, Transactions Costs and Patterns of Globalization in Developing Countries. Review of Social Economy, 60, 507-519.

Kapferer, J. N. (2012). The new strategic brand management: Advanced insights and strategic thinking. Kogan page publishers.

Keller, K.L. (2003). Strategic Brand Management: Building, Measuring and Managing Brand Equity. Englewood Cliffs: Prentice-Hall. 
Keränen, J., Piirainen, K. A., \& Salminen, R. T. (2012). Systematic review on B2B branding: research issues and avenues for future research. Journal of Product \& Brand Management, 21, 404-417.

Kotler, P. \& Pfoertsch, W. (2007). Being known or being of many: the need for brand management for business to business (B2B) companies. Journal of Business \& Industrial Marketing, 22, 357-362.

Kozinets, R.V. (2010). Netnography - Doing Ethnographic Research Online. New York: SAGE.

Kuhn, K.A., Alpert, F. \& Pope, N.K.L. (2008). An application of Keller's brand equity model in a B2B context. Qualitative Market Research: An International Journal, $11,40-58$.

Leek, S. \& Christodoulides, G. (2011). A Literature Review and Future Agenda for B2B Branding: Challenges of Branding in a B2B context. Industrial Marketing Management, 40, 830-837.

Leek, S. \& Christodoulides, G. (2012). A Framework for Generating Brand Value in B2B Markets: The Contribution of Functional and Emotional Components. Industrial Marketing Management, 41, 106-114.

Leitch, S. \& Richardson, N. (2003). Corporate branding in the new economy. European Journal of Marketing, 37, 1065-1079.

Lilien, G.L. \& Grewal, R. (2012). Handbook of Business-to-Business Marketing. Cheltenham: Edward Elgar.

Lynch, J. \& de Chernatony, L. (2004). The power of emotion: Brand communication in business-to-business markets. Brand Management, 11, 403-419. 
Lynch, J. \& de Chernatony, L. (2007). Winning Hearts and Minds: Business-to-Business Branding and the Role of the Salesperson. Journal of Marketing Management, 23, 123-135.

Marketo. (2015). Case Study - Panasonic [online]. Retrieved from: http://uk.marketo.com/customers/panasonic/ [Accessed 28 January 2015].

Meho, L.I. (2006). E-mail interviewing in qualitative research. Journal of the American Society for the Information Science and Technology, 57, 1284-1295.

Morgan, R.M. \& Hunt, S.D. (1994). The commitment trust theory of relationship marketing. Journal of Marketing, 58, 20-38.

Morris, M.H., Berthon, P. \& Pitt, L.F. (1999). Assessing the structure of industrial buying centres with multivariate tools. Industrial Marketing Management, 28, 263-276.

Mudambi, S. (2002). Branding importance in business-to-business markets, three buyer clusters. Industrial Marketing Management, 31, 525-533.

Ohnemus, L. (2009). B2B branding: A financial burden for shareholders? Business Horizons, 52, 159-166.

Panasonic Visual System Solutions. (2015). About Us [online]. Retrieved from: http://business.panasonic.co.uk/visual-system/panasonic-visual-systemsolutions/about-visual-system-solutions [Accessed 22 January 2015].

Panasonic. (2015). Corporate Profile [online]. Retrieved from: http://www.panasonic.com/uk/corporate/profile.html [Accessed 20 January 2015].

Projector Central. (2015). Projector News and Reviews [online]. Retrieved from: http://www.projectorcentral.com [Accessed 12 April 2015]. 
Projector Reviews. (2015). Newest Projector Reviews and Features [online]. Retrieved from: http://www.projectorreviews.com [Accessed 12 April 2015].

Ravald, A. \& Grönroos, C. (1996). The value concept and relationship marketing. European Journal of Marketing, 30, 19-30.

Rowley, J. (2004). Online branding. Online Information Review, 28, 131-138.

Saunders, M.N.K., Lewis, P. \& Thornhill, A. (2012). Research Methods for Business Students. New Jersey: Prentice Hall.

Schatzman, L. \& Strauss, A.L. (1973). Field Research: Strategies for a Natural Sociology. New Jersey: Prentice Hall.

Schmitz, H. (1995). Collective efficiency: growth path for small-scale industry. The Journal of Development Studies, 31, 529-566.

Srinivasan, M. \& Srivastava, P. (2012). The Role of the Salesperson in Building Trust and Collaboration in Buyer-Seller Relationships. Supply Chain Forum: an International Journal, 13, 21-37.

Tadajewski, M. \& Saren, M. (2009). Rethinking the Emergence of Relationship Marketing. Journal of Macromarketing, 29, 193-206.

Tuten, T. \& Solomon, M.R. (2013). Social Media Marketing. London: Pearson.

Tuškej, U., Golob, U., \& Podnar, K. (2013). The role of consumer-brand identification in building brand relationships. Journal of Business Research, 66, 53-59.

Ulaga, W. \& Eggert, A. (2006). Value-Based Differentiation in Business Relationships: Gaining and Sustaining Key Supplier Status. Journal of Marketing, 70, 119-136. 
Ulaga, W. (2001). Customer Value in Business Markets. Industrial Marketing Management, 30, 315-319.

Ulrich, J. \& Blut, M. (2015). Stealing the show? How the salesperson affects the industrial brand management. In: Kubacki, K. (2015). Ideas in Marketing: Finding the New and Polishing the Old. New York: Springer, 461.

Wren, B.T. \& Simpson, J.T. (1996). A dyadic model of relationships in organizational buying: A synthesis of research results. Journal of Business \& Industrial Marketing, 11, 63-79.

Yin, R.K. (2014). Case study research: Design and methods. $5^{\text {th }}$ ed. Thousand Oaks, CA: Sage.

Zahay, D., Schultz, D., \& Kumar, A. (2015). Reimagining branding for the new B2B digital marketplace. Journal of Brand Strategy, 3, 357-372. 